\title{
FACTORS INFLUENCING THE USE OF MATERNAL HEALTH SERVICES
}

\author{
Andrew Collver*, Ph.D., Ralph Ten Have*, M.D. and Mary C. Speare* \\ University of Michigan
}

\begin{abstract}
A study of low-income obstetric patients shows that rates of attendance at prenatal, postpartum and family planning clinics are associated with a variety of patients' background characteristics such as age, number of living children, and years of school completed. In addition, distance of clinics from patients' homes appeared to have a substantial effect on attendance.
\end{abstract}

IN COMPARISON with higher income groups, the poor are much less likely to obtain maternal health services such as prenatal and postnatal care, and family planning assistance [1]. The most apparent reason for this difference is inability to pay, but even when services are offered free or on a sliding scale based on ability to pay, the rate of use of the services is disappointingly low. In an effort to learn some of the reasons for low rates of attendance at maternal health clinics we interviewed 774 obstetric patients in two hospitals from late February through November of 1964, and later checked their records for attendance at postpartum clinics and at three family planning clinics. Wayne County General Hospital, just west of Detroit, provided 706 interviews and the other 68 were obtained at Sumby Hospital southwest of the city. Interviews were taken after delivery and before discharge from the hospital. The interviewers visited the hospitals regularly every Monday, Wednesday and Friday, and were instructed to see all patients on the wards. Some patients were missed by chance: for example those who were unavailable for interviews on a Friday and then were discharged before the interviewer returned on Monday. Such omissions were random, being dependent on date of delivery, and should in no way bias the results.

With the exception of five wives of interns who were on the same wards at various times, all of the patients were defined as indigent (currently receiving financial assistance from a public agency) or medically indigent (those who declared that they were unable to pay for the services of a private physician). The married women in the sample were drawn predominantly from the western and southern suburbs of Detroit, that is, from the areas adjacent to the two hospitals. The majority of the unmarried mothers, on the other hand, came from Detroit, for it was the Detroit City Physician's policy to send unmarried mothers out to the county hospital rather than to inner city hospitals.

\section{RATES OF USE OF MATERNAL HEALTH SERVICES}

Only 8 per cent of the women reported that they had failed to see a doctor for prenatal care, 27 per cent reported $1-4$ prenatal visits, 35 per cent reported $5-9$ visits and 29 per cent said they had made 10 or more visits to the doctor or clinic for prenatal care.

\footnotetext{
*Andrew Collver is a research associate and Mary C. Speare a research assistant in the Population Studies Center. Ralph Ten Have is a research associate in the Center for Population Planning.
} 
Each patient at the county hospital was instructed to return for a 6-weeks examination at the hospital postpartum clinic. After an interval of 5 months or more, we checked the patients' records to see if they had attended. Out of 706 patients scheduled for post partum care, only 244 , or 35 per cent, actually returned. It is possible that some others were able to see private physicians, but few are likely to have been able to do so.

There were a variety of opportunities available for family planning assistance. Although the fact was not publicized, any patient could obtain family planning advice at the hospital postpartum clinic if she asked for it. At the end of the hospital interview, each respondent was given a list of four family planning clinics, showing their addresses, telephone numbers and clinic hours. One was the Planned Parenthood Clinic of downtown Detroit. The second, located in Ecorse not far from Sumby Hospital, was a joint operation of the Detroit Planned Parenthood League and the School of Public Health of the University of Michigan. The third, just 2 miles east of the county hospital, was operated by the School of Public Health [2]. Another clinic on the list was located in Washtenaw County and too far distant to draw many from Wayne County. It is therefore omitted from the following discussion. A search of clinic records in April 1965 disclosed that 168, or 22 per cent of the women interviewed, obtained family planning services either at one or another of the three family planning clinics or at the postpartum clinic.

Half of the county hospital patients who received family planning assistance obtained it at the postpartum clinic. Sumby patients could obtain family planning services only at the separate family planning clinics, because there was no postpartum clinic at the hospital. As a result, the proportion of patients obtaining family planning was slightly lower for Sumby Hospital (19 per cent) than for the county hospital ( 22 per cent).

Women with high rates of prenatal clinic attendance also had high probabilities both of attending the postpartum clinic and of receiving family planning service at any of the four clinics. The percentage of county hospital patients who attended the postpartum clinic ranged from 21 for those who did not receive any prenatal care to 43 for those who had ten or more prenatal clinic checkups. Moreover, as shown in Table 1, the probability of obtaining family planning was highest among those with good records of prenatal and postpartum clinic attendance. Some women evidently had formed a pattern of consistent use of the

TABLE 1 .

NUMBER OF WOMEN, AND PERCENTAGE WHo OBTAINED FAMILY PLANNING SERVICE, BY PRENATAL VISITS AND BY POSTPARTUM CLINIC ATTENDANCE

\begin{tabular}{lccc}
\hline & \multicolumn{3}{c}{ Postpartum clinic attendance } \\
\cline { 2 - 4 } $\begin{array}{c}\text { Number of } \\
\text { prenatal visits }\end{array}$ & Attended & Did not attend & Total \\
\hline & 11 & A. & Number of women \\
None & 53 & 54 & 65 \\
$1-4$ & 88 & 157 & 210 \\
$5-9$ & 92 & 187 & 275 \\
10 or more & 244 & 132 & 224 \\
\hline Total & B. & Percentage who obtained family planning \\
\hline & 9 & 7 & 8 \\
None & 43 & 8 & 17 \\
$1-4$ & 49 & 12 & 24 \\
$5-9$ & 53 & 11 & 28 \\
10 or more & 48 & 10 & 22 \\
\hline Total & \multicolumn{4}{c}{}
\end{tabular}


medical services available to them, while others used the services sporadically if at all. The figures show a striking difference: among those who had ten or more prenatal checkups and attended the postpartum clinic, 53 per cent received family planning service, in contrast to only 7 per cent among those who had neither prenatal nor postpartum examinations. Evidently those who had availed themselves of services in the past were more likely than others to continue using the services.

The remainder of this report is devoted to an examination of factors tending to increase or decrease the probability that a woman would attend clinics for prenatal, postpartum and family planning services.

\section{THE PREDICTOR VARIABLES}

The hospital interview provided background information on the patients together with indications of their previous and anticipated use of birth control. Questions covered items such as number of living children, marital status, age, race, religious preference, frequency of church attendance, education, and number of years of residence in Detroit. Home addresses were asked for and later coded by coordinates on a map. Each patient was asked about the size of the community she lived in as a child. Additional questions covered the number of children wanted, attitudes toward family limitation in general, intentions to use some method to prevent pregnancy, methods of birth control already used, and methods preferred. Early in the interview each respondent was asked whether she knew about four family planning clinics in the area. Later she was given a list of the clinics and asked to name the one that she would most likely attend.

Certain classifications originally intended for analysis were dropped from further study upon examination of initial results. For example, we thought that newcomers to the Detroit area would be less likely to attend clinics because they had not yet learned their way around the community. Actually we found that 90 per cent of the women interviewed had lived in the city at least 3 years and 85 per cent more than 6 years. Thus ignorance because of newness in the community could not have been an important factor limiting clinic attendance. When asked to indicate which clinics they had heard about, respondents were most likely to name the clinic nearest to their home. Because this question seemed to indicate nothing more than proximity of the clinics, we omitted it from any further analysis.

The interviewers found it difficult to classify people according to the size of community where they had spent their childhood. Given the uncertainty of classification and the small numbers replying "farm" or "small town" background (34 and 97 respectively), the results from this question appeared to be of doubtful value. Moreover, we could find no consistent pattern of association between size of community of childhood and clinic attendance.

Several questions were asked regarding the women's intentions to use birth control. Those who said they planned to attend a clinic were more likely than others to do so, but we found that both intended and actual attendance were determined by other more objective characteristics such as age, marital status, number of living children and accessibility of clinics. Once we had taken these variables into account, expressed intentions added no further precision to our predictions of clinic attendance. Similarly, women who said that they preferred clinical methods of family planning were a little more likely to attend clinics than were those who preferred non-clinical methods, but we found that a preference for clinical methods had no predictive value once the objective characteristics were taken into account. Women who said they already had more children than they wanted were more likely than others to attend a family planning clinic, but this difference also vanished when 
the more objective variables were controlled. All-in-all the objective characteristics proved to be better predictors than the respondents' expressed attitudes or intentions.

The objective characteristics (e.g., age, marital status or number of living children) may be understood as operating in two ways to influence clinic attendance. First, they produce predispositions or tendencies on the part of the women themselves, and secondly they call forth differential treatment in the maternal care system. Not only did women with large families feel a greater need for family planning; they were also more strongly urged to obtain the assistance they wanted. Whatever their personal reasons for wanting or not wanting clinical care, the unmarried mothers experienced some discriminatory treatment that tended to discourage them from attending. Young unmarried girls were almost always sent for delivery to the county hospital rather than to the nearest hospital. Also they would experience some difficulty with the eligibility requirements of Planned Parenthood. Public health nurses at that time were not permitted to mention birth control to the unmarried patients.

\section{DIFFERENTIAL USE OF SERVICES}

Attendance at clinics was systematically related to several background characteristics of the patients interviewed. Some of these relationships are shown in Table 2.

Nearly two-thirds of the women interviewed said that they had seen a doctor for prenatal care at least five times. Age made little difference in the probability of obtaining prenatal care. The proportion obtaining standard prenatal care was higher among women in their first pregnancies than among those who already had children. Married women were a little more regular in obtaining care than the unmarried. Education had a very strong positive association with prenatal attendance. There was practically no difference between Negroes and whites. When the women are divided by religion and church attendance, the Protestant frequent attenders appear to have had the highest level of prenatal care and Catholic frequent attenders the lowest.

One-third of the patients at the two hospitals returned for their postpartum checkups. The proportion doing so increased with age, from 21 per cent of those 13-17 to 42 per cent of those over 30 years old. Some of the characteristics associated with a relatively high rate of clinic attendance were high parity, being currently married, having a high level of educational attainment, and being of the white race. Religion showed no association with postpartum attendance.

Out of the 774 women followed up after delivery, 22 per cent obtained family planning service. The proportion obtaining this service increased markedly with both age and parity. Married women were twice as likely to ask for family planning as other women. Education again had a positive association. Negroes were a little more likely than whites to attend a clinic for family planning. Frequent church attenders were less likely than infrequent attenders to obtain this service. Being of the Catholic faith apparently reduced acceptance of family planning only for those who were frequent church attenders.

The relationships shown in Table 2 are merely the gross relationships obtained by classifying on the basis of one characteristic at a time. As such they must not be interpreted as indications of causal effects. The girls aged 13-17 were likely to be single and to have low parity. At this point we cannot tell whether the low rates of clinic attendance of the youngest age group were due to their youth, their marital status, their parity or some other associated characteristic. Before discussing the significance of the differential rates of clinic attendance, it will be necessary to separate the individual associations of several variables that are highly correlated with one another. 
TABLE 2.

Percentage of Women receiving prenatal, postrartum, and FAMILY PLANNING SERVICES BY SELECTED CHARACTERISTICS

\begin{tabular}{|c|c|c|c|c|}
\hline & \multicolumn{4}{|c|}{ Percentage who received services } \\
\hline & $\begin{array}{l}\text { No. of women } \\
\text { in category }\end{array}$ & Prenatal & Postpartum & $\begin{array}{l}\text { Family } \\
\text { planning }\end{array}$ \\
\hline $\begin{array}{l}\text { Age* } \\
13-17 \\
18-20 \\
21-24 \\
25-29 \\
30 \text { and over }\end{array}$ & $\begin{array}{r}160 \\
184 \\
212 \\
120 \\
98\end{array}$ & $\begin{array}{l}60 \\
71 \\
67 \\
54 \\
65\end{array}$ & $\begin{array}{l}21 \\
30 \\
33 \\
36 \\
42\end{array}$ & $\begin{array}{r}8 \\
21 \\
28 \\
25 \\
29\end{array}$ \\
\hline $\begin{array}{l}\text { No. of living children } \\
\begin{array}{l}0-1 \\
2-3 \\
4-13\end{array}\end{array}$ & $\begin{array}{l}287 \\
280 \\
207\end{array}$ & $\begin{array}{l}70 \\
62 \\
59\end{array}$ & $\begin{array}{l}29 \\
30 \\
38\end{array}$ & $\begin{array}{l}12 \\
24 \\
34\end{array}$ \\
\hline $\begin{array}{l}\text { Marital status } \\
\text { Married } \\
\text { Other } \dagger\end{array}$ & $\begin{array}{l} \\
477 \\
297\end{array}$ & $\begin{array}{l}66 \\
61\end{array}$ & $\begin{array}{l}38 \\
23\end{array}$ & $\begin{array}{l}27 \\
13\end{array}$ \\
\hline $\begin{array}{l}\text { Education } \\
\text { Grade school or less } \\
\text { Some high school } \\
\text { Completed high school } \\
\text { Beyond high school }{ }_{+}^{+}\end{array}$ & $\begin{array}{r}82 \\
444 \\
216 \\
32\end{array}$ & $\begin{array}{l}47 \\
64 \\
68 \\
84\end{array}$ & $\begin{array}{l}26 \\
28 \\
37 \\
56\end{array}$ & $\begin{array}{l}22 \\
18 \\
28 \\
34\end{array}$ \\
\hline $\begin{array}{l}\text { Race } \\
\text { Negro } \\
\text { White }\end{array}$ & $\begin{array}{l}378 \\
3.96\end{array}$ & $\begin{array}{l}65 \\
63\end{array}$ & $\begin{array}{l}28 \\
36\end{array}$ & $\begin{array}{l}24 \\
20\end{array}$ \\
\hline $\begin{array}{l}\text { Religion and church } \\
\text { attendance§ } \\
\text { Prot. frequent } \\
\text { Prot. infrequent } \\
\text { Cath. infrequent } \\
\text { Cath. frequent }\end{array}$ & $\begin{array}{r}317 \\
326 \\
67 \\
64\end{array}$ & $\begin{array}{l}67 \\
62 \\
61 \\
59\end{array}$ & $\begin{array}{l}34 \\
31 \\
30 \\
32\end{array}$ & $\begin{array}{l}21 \\
24 \\
24 \\
14\end{array}$ \\
\hline Total & 774 & 64 & 32 & 22 \\
\hline
\end{tabular}

*The rationale for the age groupings is as follows: girls under 18 are normally expected to be attending high school; those over 18 are old enough to have completed high school and are legally eligible to marry without parents' consent; 21 is the age of full adult status.

†Single, separated, widowed or divorced.

$\ddagger$ Attended college or technical training school after high school.

\$Included with Protestants are 29 who expressed no religious preference (19 of whom said they attended church sometimes) and 3 who reported religions other than Protestant, Catholic, or Jewish. Frequent church attendance is defined as at least twice a month for Protestants and at least once a week for Catholics.

\section{ACCESSIBILITY AND THE USE OF SERVICES}

We expected that the distance women had to travel to reach medical services would affect attendance rates, since those living farther away would find it more difficult to get to clinics. We were unable to test this notion with respect to prenatal care, for we did not know how far each woman had to travel for this service. However, we did obtain the information relevant to postpartum clinic attendance and family planning services.

For the prediction of postpartum clinic attendance by county hospital patients, we used as one of our variables the distance to the hospital from the center of the census tract in which each woman lived. As expected, the probability of attendance decreased with in- 
creasing distance from the county hospital. The percentage attending the postpartum clinic varied from 49 for women living less than 5 miles from the hospital to 31 for those $5-12$ miles away to 14 for those more than 12 miles away.

The measurement of accessibility of the family planning services had to be more complex because there were four clinics instead of one as in the case of the postpartum clinic. The simplest measure of accessibility is the straight-line distance from the patient's home to the nearest family planning clinic. In the analysis it turned out that distance to the nearest clinic had no relation with the probability of attending any clinic other than the nearest. Regardless of the distance to the nearest clinic, the probability of attending some other clinic remained constant, about $0 \cdot 10$. This is a very significant observation, for it indicates that, at least at the low level of clinic attendance then prevailing, the nearest clinic did not gain its patients at the expense of the more distant clinics.

Attendance at the nearest clinic, on the other hand, dropped off very steeply from 25 per cent of those living within a mile of the nearest clinic to 11 per cent in the $1-4$ mile zone and only 1 per cent among those living 5-7 miles from the nearest clinic. However, beyond that distance the rate of attendance at the nearest clinic again rose to form a second peak of 17 per cent at 8-10 miles, before finally dropping back to zero at 13 miles and over. On the basis of this irregular pattern it seems evident that simple distance to the nearest clinic is not a satisfactory predictor of clinic attendance.

We can suggest two reasons for the inadequacy of the measure. One is that distance to the nearest clinic does not indicate the relative accessibility of that clinic when there are a number of alternative places to go for the same service. Since accessibility is a matter not only of straight-line distance but also of the cost and convenience of transportation, and of factors determining psychological accessibility, it will often happen that the closest of four points will not actually be the most accessible. The second reason is that the clinics may vary in their attractiveness or "drawing power". This being the case, one clinic may exert as much attraction at a radius of 6 miles as another does at only 3 or 4 miles. The simple distance measure fails to take into account irregularities of transportation and differences in the acceptability and attractiveness of different clinics.

For these reasons and others to be discussed below we decided to use a composite measure of distance to all clinics rather than distance to the nearest one. Our reasoning in the use of the composite measure is that each additional clinic offered in a community increases the opportunities for, and hence the rate of, clinic attendance. This increase in attendance is brought about in three ways. (1) Each additional clinic increases the choice of transportation routes and thereby increases the probability that a prospective patient will find a convenient way to reach a clinic. (2) Each additional clinic increases the range of choice of auspices and styles of operation and hence the likelihood that a prospective patient will find a clinic that suits her preference. (3) Each additional clinic provides a center from which influence may be exerted-it has a publicity impact on its surrounding territory.

A satisfactory composite measure of accessibility to a number of clinics should be consistent with the following hypotheses. (1) The probability that prospective patients from a given residential location will attend any family planning clinic is inversely proportional to the distance they must travel to reach a clinic. (2) Each additional clinic offered will increase the probability of clinic attendance, subject to the following limitations: (a) its impact on attendance will be inversely proportional to its distance from the residential location, and (b) there are "diminishing returns" to additional clinics. If one clinic exists in a neighbor- 
hood and draws 25 per cent of the prospective patients from that neighborhood, and then a new clinic is opened a block away, the new clinic cannot be expected to draw an additional 25 per cent. The reason for this is that the first patients recruited are the most willing and ready for the services. The second 25 per cent are harder to recruit. Eventually, if attendance reaches 100 per cent, additional clinics can have no impact whatsoever on the rate of attendance.

Accordingly, we computed a measure of accessibility $(A)$ by the following formula in which $d_{1}$ is the distance from a person's home to the first clinic, $d_{2}$ is the distance to the second clinic, $d_{3}$ to the third and $d_{4}$ to the fourth. $A=10 / d_{1}+10 / d_{2}+10 / d_{3}+10 / \mathrm{d}_{4}$. The numerator, 10 , in each fraction is an arbitrarily selected weight for each clinic. Probably these weights should not all be equal. Some clinics are more attractive than others, or carry on more aggressive publicity efforts. However, as a first approximation in the absence of any estimates of attractiveness of the different clinics, we have left the weights equal [3]. If an individual lived in a community in which there was only one clinic and it was 10 miles from her home, her index of accessibility would be $1 \cdot 0$. If a second clinic were added one mile from her home, her accessibility would rise to $10 / 10+10 / 1=11$. Each new clinic opened in her community would similarly add to her index of accessibility. Values on the index for our sample of women in Wayne County ranged from a low of almost zero to a high of 38. The index is not a prediction of the probability of attending a clinic, but is merely an a priori measure of exposure to the opportunity to attend. The equation for the relation between accessibility and attendance has to be found empirically.

We grouped the women interviewed into five zones of accessibility and found the percentage of women attending family planning clinics in each zone. The results are shown in Table 3. Clinic attendance increases continuously as accessibility increases. There is no reversal of the trend such as was found in relation to the distance to the nearest clinic. The model appears to provide a good fit to the data, and it would be possible at this point to write an equation expressing the relation between accessibility and clinic attendance. However, this would be premature, for we should first remove the effects of other variables that are correlated with accessibility.

TABLE 3.

Percentage of Women attending any Clinic for FAMILY PLANNING, BY ACCESSIBILITY TO CLINICS

\begin{tabular}{cccc}
\hline Accessibility* & $\begin{array}{c}\text { Total } \\
\text { number of } \\
\text { women }\end{array}$ & \multicolumn{2}{c}{ Received family planning } \\
\hline $0-4$ & 140 & 19 & $(\%)$ \\
\hline $5-9$ & 353 & 63 & 14 \\
$10-15$ & 172 & 46 & 18 \\
$16-29$ & 45 & 15 & 33 \\
$30-38$ & 64 & 25 & 39 \\
\hline Total & 774 & 168 & 22 \\
\hline
\end{tabular}

*Accessibility is a composite measure of location with reference to four clinics. For method of calculation, see text.

\section{DISTINGUISHING THE EFFECTS OF DIFFERENT VARIABLES}

Having seen how clinic attendance rates are systematically related to a variety of background characteristics and to accessibility, our next step was to try to isolate the individual 
effects of each characteristic. This step was necessary because of the high degree of association among the characteristics being used to predict clinic attendance. For example, the younger women tended to have low parity; many of them were single; many were still in high school or had dropped out without completing high school; a large percentage of them were Negro; and they had a higher frequency of Protestant church attendance than the older women. In comparing the behavior of younger and older women, then, it is important to estimate to what extent the observed differences are due to differences in age per se, and to what extent they are produced by correlated differences in parity, marital status, education, etc. Single women had a much lower rate of clinic attendance for family planning than married women. Was this because of their marital status, or because they tended to be younger, or of low parity? Similar problems arise in attempting to isolate the effects of each of the other variables.

To do this we used a procedure known as multiple-classification analysis. The model for this procedure assumes that each variable has an independent effect and that all the effects are additive [4]. Each attribute is conceived as tending to raise or lower the value of the dependent variable, in this case the probability of clinic attendance. The percentage expected to attend a clinic out of a group of women who are homogeneous on eight attributes* is given by the equation $P_{c}=P+a+b+\ldots+h$, in which $P$ is the average attendance for all women and the letters $a, b, \ldots h$ represent the effects of the respective attributes.

\section{THE PREDICTION EQUATIONS}

Using multiple classification analysis, we computed the net effects of a set of independent variables on attendance at clinics for prenatal care, for postpartum examinations and for family planning. In the strict sense these cannot properly be called predictions, for they were derived from the data after the facts of attendance or non-attendance had been recorded. This being the case, the results strictly interpreted comprise a set of measures of association between clinic attendance and other characteristics among the women studied. However, on the assumption that there is some stability of characteristics over time in the population represented by the study we offer the results in the form of predictions.

\section{Prenatal care}

Sixty-four per cent of the women interviewed said that they had made five or more visits to the doctor for prenatal care. Given some knowledge about different individuals or subgroups we should be able to account for differences in their rates of attendance for this service, and by inference from past behavior, offer a multiple prediction equation for prenatal clinic attendance. The coefficients for such an equation are shown in Table 4. Women in their first pregnancy had a much higher probability of faithful attendance for prenatal care $(+11)$ than those who were in their second or third pregnancy $(-6)$ or in the fourth through thirteenth $(-7)$. Being over 30 years of age increased the probability of

\footnotetext{
*When applied to a group in which the members are not homogeneous on the predictor variables, the prediction must be made by a weighted average of the effects of all categories of all variables. Representing each variable by a subscript, $j$, each category of the variable by a second subscript, $k$, the net effect of each category by $b$ and the proportion of individuals in the category by $p$, we have an equation of the form $P_{c}=P+\Sigma \Sigma p_{j k} b_{j k}$. (Note: $\Sigma p_{j}=1$ ).

In expanded form, if there are three variables and each variable has two categories, $\boldsymbol{P}_{c}=\boldsymbol{P}+p_{11} b_{11}+p_{12} b_{12}+p_{21} b_{21}+p_{22} b_{22}+p_{31} b_{31}+p_{32} b_{32}$.
} 
J ABLE 4.

NET EFFECTS OF PREDICTOR VARIABLES ON THE PERCENTAGE MAKING FIVE OR MORE PRENATAL VISITS TO DOCTOR OR CLINIC*

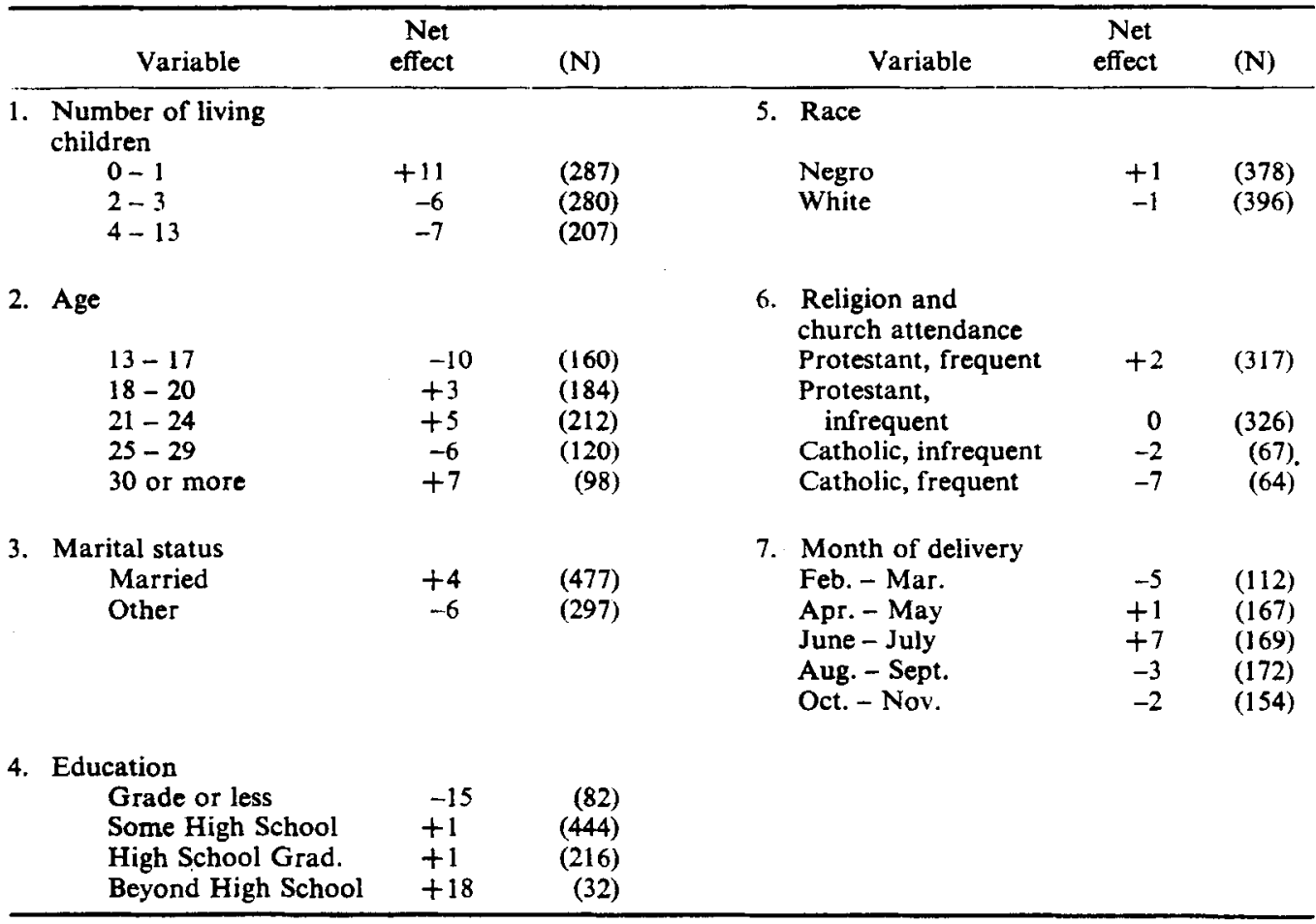

*A total of 499 women or 64 per cent made five or more visits to doctor or clinics for prenatal care.

attendance by 7 per cent, married women were more regular in their use of prenatal services than unmarried women $(+4$ against -6$)$, Negroes slightly more regular than whites and so on.

If we accept five visits as the minimum standard for prenatal care, the percentage receiving standard prenatal care is predicted as follows for women in their first pregnancy, over 30 years of age, married, who have had some formal education beyond high school, Negro, Protestant frequent church attenders, who delivered in June or July: $P_{c}=64+11+7+$ $4+18+1+2+7=114$. The obvious overestimation of 114 per cent occurs because the net effects of the different variables shown in Table 4 are the average effects for all women in the sample. If we select a hypothetical extreme group in which all characteristics tend to maximize clinic attendance, there must necessarily be some scaling down of the effects of each variable. Clinic attendance can only be pushed up to 100 per cent and no farther. The net effects should therefore be interpreted in this manner: If we have a group of 100 women and on the basis of their other characteristics we expect 64 of them to make five or more visits to prenatal clinics, then if we know that all of these women are in their first pregnancy we will expect $64+11=75$ of them to have a good attendance record. However, if on the basis of their other characteristics we already expect 95 of the women 
to attend five or more times, then knowing that they are in their first pregnancy can only increase our prediction by 5 at the most. $\dagger$

The predicted attendance for women with 4 or more children under 18 years of age, unmarried, with no more than a grade school education, white, Catholic frequent church attenders, delivered in February or March is $P_{c}=64-7-10-6-15-1-7-5=13$. From the range of the high and low predictions we can see that the seven independent variables taken together can have a strong influence on the rate of prenatal clinic attendance.

\section{Postpartum clinic attendance}

In Table 5 are the coefficients for predicting attendance at the postpartum clinic. According to these results, the highest attendance rate, 95 per cent, will be found among women with 0-1 living children, over 30 years old, married, high-school educated, Negro. Protestant frequent attenders, who delivered in February or March and who lived within five miles of the county hospital. We could not discover any satisfactory explanation for the high rate of attendance among those with February and March deliveries. One could speculate that they were especially glad to go out in the spring, after having been confined for a few months by winter's severe weather. At the other extreme, the calculated attendance rate for those with the most unfavorable set of characteristics is -3 per cent.

\section{Obtaining family planning services}

High parity, high school education, high accessibility to clinics and delivery in the months of October and November are the characteristics tending most strongly to raise attendance for family planning. The maximum and minimum predictions for family planning attendance calculated from the net effects in Table 6, are 80 and-24. Although the power of the eight variables in the table to reduce family planning attendance is obviously exaggerated here, the equations do indicate the relative magnitudes of the influence of different variables. Even when the effects of seven other characteristics are removed, the rate of acceptance of family planning appears to have increased markedly among women who delivered in October and November. This is because in December when these women were having their six-weeks checkups the county hospital began openly offering family planning to all women at the postpartum clinic instead of waiting for the patients to initiate requests for the service.

†The technique by which the net effects were computed does not give any indication of the way in which effects diminish as the percentages approach zero or 100. Perhaps a logistic curve would provide an adequate correction. The logistic curve

$$
Y=\frac{100}{1+\mathrm{e}^{(a+b x)}}
$$

is symmetrical and S-shaped, with a lower limit of zero and an upper limit of $100 . Y$ is the predicted percentage attending clinics; $x$ is the sum of net effects of a set of predictor attributes

$$
\left(x=P_{c}-P\right) \text {; }
$$

$a$ is the exponent required in the equation $\quad e^{a}=\frac{100}{P}-1$;

and the constant $b$ is a small negative quantity, on the order of $-0 \cdot 06$. Applying the formula

$$
Y=\frac{100}{1+\mathrm{e}^{(1 \cdot 27-0 \cdot 06 x)}}
$$

to calculate a corrected prediction of family planning attendance (where $P=22$ ), instead of predictions in the range $-24<P_{c}<80$, we get a range of $7<Y<89$. 
TABLL 5.

NET EFFECTS OF PREDICTOR VARIABLES ON THE PERCENTAGE OF WOMEN ATTENDING POSTPARTUM CLINIC (COUNTY HOSPITAL PATIENTS ONLY)*

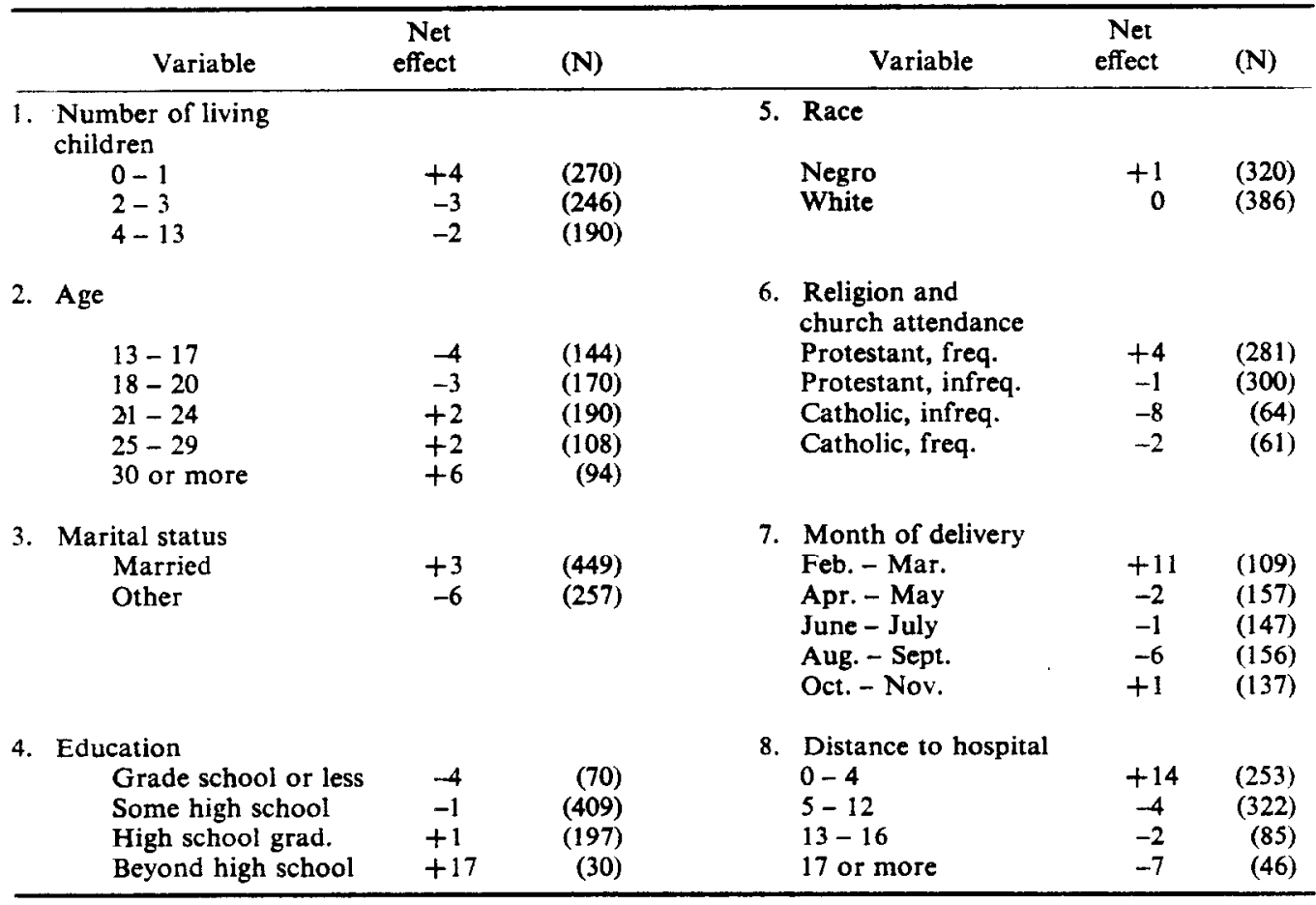

*The number of County Hospital patients is 706 , of which 244 , or 35 per cent, attended postpartum clinic.

\section{Accessibility and family planning attendance}

When the net effects of accessibility from Table 10 are added to the sample mean of 22 , the result is clinic attendance for family planning by accessibility standardized for seven other variables. When this relation is plotted on a logarithmic graph, the points form a straight line. Letting $P_{c}$ stand for the calculated percentage of women who received family planning and $A$ stand for the index of accessibility, the linear relationship is $\log P_{c}=\log$ $12.5-0.26 \log A$. Then $P_{c}=12.5 A^{0.26}$. This equation provides a virtually perfect fit to the data and complies fully with the theoretical requirements previously stated. Its general form is $P_{c}=K A$ b. There are three variables determining $P_{c} . K$ is a constant representing the clinic attendance rate where accessibility is $1 \cdot 0$. In the present case its value is $12 \cdot 5$. In a community with only one clinic, this is the rate of attendance for women living 10 miles from the clinic. $A$, the measure of accessibility, increases for all census tracts as each new clinic is added to the community but increases most markedly in the immediate vicinity of the new clinic. Accessibility may also be modified by differences in the relative "attractiveness" of the different clinics - that is by the varying effectiveness of their patient recruitment efforts-but we have not taken this variability into account. Finally, the exponent, $b$, which must be less than 1.0, expresses the diminishing returns to increments of accessibility. The exponent of 0.26 calculated from our data indicates that a great increase in clinic attendance 
can be produced by raising accessibility up to about 10 (equivalent to having one clinic 1 mile away, two clinics each 2 miles away, or three clinics each 3 miles away) but that further increases in accessibility have relatively little effect on clinic attendance. (See Table 7.)

TABLE 6.

Net efFects of PREDictor VARIAbles ON the PERCENTAGe OF WOMEN Who OBTAINED BIRTH CONTROL SERVICES AT ONE OF THE CLINICS*

\begin{tabular}{lcc}
\hline \multicolumn{1}{c}{ Variable } & $\begin{array}{c}\text { Net } \\
\text { effect }\end{array}$ & $(\mathrm{N})$ \\
\hline $\begin{array}{l}\text { 1. Number of living } \\
\text { children } \\
0-1\end{array}$ & & \\
$2-3$ & -8 & $(287)$ \\
$4-13$ & -2 & $(280)$ \\
& +13 & $(207)$ \\
2. Age & & \\
& & \\
$13-17$ & 0 & $(160)$ \\
$18-20$ & +3 & $(184)$ \\
$21-24$ & +3 & $(212)$ \\
$25-29$ & -6 & $(120)$ \\
30 or more & -7 & $(98)$
\end{tabular}

3. Marital status

$\begin{array}{lll}\text { Married } & +3 & (477) \\ \text { Other } & -5 & (297)\end{array}$

4. Education

$\begin{array}{lcr}\text { Grade or less } & -2 & (82) \\ \text { Some High school } & -4 & (444) \\ \text { High school grad. } & +6 & (216) \\ \text { Beyond High school } & +15 & (32)\end{array}$

7. Month of delivery

$\begin{array}{lcc}\text { Feb. - Mar. } & +3 & (112) \\ \text { Apr. - May } & -7 & (167) \\ \text { June - July } & 0 & (169) \\ \text { Aug. - Sept. } & -4 & (172) \\ \text { Oct. - Nov. } & +10 & (154)\end{array}$

8. Accessibility

$\begin{array}{lrr}0-4 & -7 & (140) \\ 5-9 & -1 & (353) \\ 10-15 & +3 & (172) \\ 16-29 & +7 & (45) \\ 30-38 & +9 & (64)\end{array}$

*A total of 168 women, or 22 per cent, obtained birth control at one or another of the four clinics.

TABLE 7

Calculated rates of family planning clinic attendance, FOR DIFFERENT LEVELS OF ACCESSIBILITY

\begin{tabular}{cccc}
\hline $\begin{array}{c}\text { Number of clinics } \\
\text { located one mile } \\
\text { away from prospective } \\
\text { patients' homes }\end{array}$ & Accessibility* & $\begin{array}{c}\text { Percentage of } \\
\text { prospective } \\
\text { patients expected } \\
\text { to attend } \dagger \\
\left(P_{c}\right)\end{array}$ & $\begin{array}{c}\text { Increase of } \\
\text { attendance } \\
\text { produced by } \\
\text { additional } \\
\text { clinic }\end{array}$ \\
\hline 0 & 0 & 0 & -2 \\
1 & 10 & 23 & 23 \\
2 & 20 & 29 & 6 \\
3 & 30 & 31 & 1 \\
5 & 40 & 32 & 1 \\
\hline
\end{tabular}

*Accessibility is a composite measure of location with reference to four clinics. For method of calculation see text.

†Percentage expected to attend is calculated by the equation: $P_{c}=12 \cdot 5 A^{0 \cdot 26}$, 


\section{SUMMARY AND CONCLUSIONS}

Utilizing information on maternity patients in two hospitals in the Detroit area, we have attempted to measure the importance of a number of variables influencing the probability of attending clinics for maternal health services.

One striking result is that expressed attitudes or intentions of the patients themselves contribute nothing additional to the prediction of attendance rates once a set of objective characteristics, including number of living children, age, marital status and education, has been taken into account.

In comparing the findings regarding the use of prenatal services, postpartum care, and family planning, we can see that some characteristics were associated in quite different ways with the rates of use of the different services. The use of prenatal and postpartum care was higher among those of low parity, but it was the women with large families who sought family planning services. The use of prenatal and postpartum services tended to increase with age, but older women tended to have low rates of family planning clinic attendance.

Other variables had consistent associations with all three services. Married women were consistently more likely to visit clinics than other women. More education tended to increase the likelihood of making use of all three types of health services. Negroes were consistently more likely than whites to attend any of the clinics.

Religion had mixed relations with the use of maternal health services. Catholics tended to have low rates of attendance at all three types of clinic, except that those who attended church infrequently were more likely even than Protestants to attend family planning clinics.

Some substantial differences in clinic attendance by month of delivery appeared, but except for the increased rate of acceptance of family planning at the end of the study period, we are not prepared to say what may have caused these apparent "seasonal" fluctuations.

The relationships brought out in this study have some practical implications. For one thing, we have clearly demonstrated the effect of accessibility on clinic attendance. One way of overcoming this effect is to place branch clinics in scattered strategic locations. Our data suggest that, at least in the Detroit area, these branches should be placed not more than ten miles apart, so that patients will not need to travel more than five miles to keep their appointments. We do not mean to imply that a pattern of branch clinics is the only way to overcome the effects of distance on attendance. Accessibility may also be increased by the use of mobile clinics or by providing transportation to more centrally located facilities. Secondly, we have identified certain categories of women who because of their background characteristics are highly unlikely to attend clinics for maternal health services. For example, young unmarried mothers with less than a high school education had a low probability of postpartum clinic attendance. Women such as these present the main problem for those concerned with finding ways to recruit patients and increase clinic attendance rates.

Acknowledgements-The interviews and the two study clinics mentioned in this report were financed primarily by a grant from the Population Council for the Michigan Intra-Uterine Contraceptive Study under the direction of Johan W. Eliot, M.D. The analysis was financed by the Ford Foundation through the general fund of the Population Studies Center.

\section{REFERENCES}

1. Yfrky, Alonzo S. The disadvantaged and health care, Am. J. of Publ. Hlth, 56, (January 1966), Part I, pp. 5-9. 
2. Have, Ralph TeN and Collver, Andrew. Family planning clinics for the urban fringe, Am. J.of Publ. Hlth., 56 (January 1966), Part II, pp. 61-66.

3. For a bibliography and commentary on relationships of this type, see GUNNAR OLSSON, Distance and Human Interaction, Philadelphia: Regional Science Research Institute, Bibliography Series, No. 2, 1965. especially pp. 43-70.

4. For a discussion of the basic rationale of the method, see DANIEL B. SuIts, The use of dummy variables in regression analysis, J. of the Amer. Statist. Ass., 52 (December 1957), pp. 548-551. Technicul details of computation are described in JAMES N. MORGAN, et al. Income and Welfare in the United States, McGraw-Hill, New York, 1962, Appendix E.

Résumé-En cherchant les raisons de l'utilisation réduite de services de santé maternelle, les investigateurs interviewèrent $\mathbf{7 7 4}$ malades dans les services d'obstétrique, dans deux hôpitaux près de Detroit, en 1964, et puis ils les suivirent de près dans les cliniques post-natales et dans trois cliniques de planification familiale. La majorité de malades provenaient de familles avec un revenu modeste.

Des soins prénatals adéquats, définis comme cinq visites ou plus dans les cliniques prénatales furent rapportées dans 64 pour cent de femmes interviewées. Subséquemment les archives de cliniques montrèrent que 35 pour cent de malades désignées pour les cliniques postnatales vinrent réellement pour ce service et que 22 pour cent de toutes les femmes interviewées demandèrent l'aide de planification familiale dans une de ces cliniques. Les femmes avec une bonne notation concernant la visite de cliniques prénatales visitèrent davantage les cliniques postnatales et demanderent des conseils pour planification familiale.

Trois groupes de caractéristiques furent investiguées pour trouver une association avec la fréquentation de cliniques. Le premier groupe, avec de caractéristiques subjectives, incluait des malades qui exprimaient leurs attitude envers les cliniques, et montraient leurs intention de les visiter ou non. Le second groupe consistait de caractéristiques plus objectives, incluant le nombre d'enfants vivants, l'âge, la situation matrimoniale, l'éducation, la race, les préférences religieuses et le nombre de visites à l'église. Le troisième groupe incluait deux variables circonstantielles: la distance du domicile de patients jusqu'à la clinique et le mois de la délivrance.

A cause de substantielles intercorrélations parmi ces variables, il fût nécéssaire d'introduire des vérifications statistiques pour montrer "les effets statistiques nets" de chaque variable concernant la fréquentation clinique, en éloignant en même temps les effets d'autres variables. Le procédé choisi pour cette "analyse par classification multiple" produisit un groupe d"équations capable de prédire la fréquentation clinique.

L'analyse montre que les attitudes ou intentions exprimées par les patientes ne contribuent de rien à la prédiction de la proportion de fréquentation, du moment que les caractéristiques objectives sont prises en considération.

Toutes les variables objectives mentionnées, avaient des associations appréciables avec la fréquentation de cliniques. Quelques unes avaient des rélations tout à fait différentes avec le degré d'utilisation de services de santé maternelle. Par exemple, l'utilisation de services pré et postnatals fût plus grande parmi les femmes avec peu d'enfants; mais les femmes avec beaucoup d'enfants fréquentaient les services de planification familiale. Autre variables - condition matrimoniale, éducation et race-eurent d'associations consistantes avec les trois services. La religion eut des effets variés.

L'acceptation de la planification familiale augmenta à la fin de la période d'études, quand les services furent offerts dans les cliniques post-natales.

L'effet de la distance sur la fréquentation clinique fût clairement démontré. La fréquentation de cliniques post-natales baissa brusquement en rapport avec la distance de l'hopital. La probabilité de fréquentation de n'importe quelle clinique dépendant également de la facilité d'accessibilité aux 4 cliniques.

Une implication pratique de cette étude est que ce type d'analyse peut être utilisé pour distinguer des catégories spéciales de femmes qui ont besoin d'un peu plus d'encouragement pour visiter les cliniques. Egalement il est suggéré que la fréquentation peut être augmentée sensiblement en utilisant des cliniques dispersées, pour augmenter l'accessibilité.

Sumario-Tratando de encontrar razones que expliquen el reducido uso de los servicios de salud maternal, los investigadores entrevistaron en 1964 a 774 pacientes en las salas de obstetricia de dos hospitales próximos a Detroit y, más tarde, tomaron nota de la frecuencia con que dichas mujeres asistieron a las clínicas postnatales y a las tres clínicas de planeamiento de familia. La mayor parte de las pacientes provenfan de familias con ingresos bajos. 
Según las declaraciones de las mujeres en las entrevistas, un 64 por ciento de ellas habian tomado cuidados prenatales adecuados, cuidados que se definen como cinco o más visitas a las clínicas prenatales. Los registros clínicos demostraron posteriormente que, de las pacientes con quienes se habla hecho arreglos para que acudieran a clínicas postnatales, el 35 por ciento asi lo hicieron, y que el 22 por ciento de todas las madres entrevistadas se acogieron a los servicios de planeamiento de familia en una u otra de las clínicas. Las mujeres que habian asistido con frecuencia a las clinicas prenatales tenfan una alta probabilidad de acudir tambien a las clínicas postnatales y de solicitar los servicios de planeamiento de familia.

Se investigaron tres grupos de caracteristicas en relación con la asistencia a las clínicas. El primer grupo, caracteristicas subjetivas, incluia las actitudes expresadas por las pacientes hacia sus clinicas y sus intenciones de visitarlas o no visitarlas. El segundo grupo consistia de características más objetivas, tales como el número de hijos vivos, edad, estado marital, educación, raza, religión y la frecuencia de asistencia a la iglesia. El tercer grupo incluia dos circunstancias variables: la distancia de las casas de las pacientes a la clínica y el mes del parto.

A causa de las notables intercorrelaciones entre estas variables, fué necesario introducir controles estadísticos para mostrar los "efectos estadísticos netos" de cada variable sobre la asistencia a la clínica, eliminándose los efectos de las otras variables. El método seleccionado para este análisis de clasificación múltiple produce una serie de ecuaciones para predecir la asistencia a las clínicas.

El análisis muestra que las actitudes expresas o las intenciones de las pacientes no contribuyen nada adicional a la predicción de la asistencia una vez de que se ha tomado en cuenta las caracteristicas objetivas.

Todas las variables objetivas mencionadas estaban asociadas apreciablemente con la asistencia a las clínicas. Algunas de esas variables tentan muy diferentes relaciones con la frecuencia del uso de los distintos servicios de salud maternal. Por ejemplo, las mujeres con pocos hijos usaron con mayor frecuencia los servicios pre y postnatales, mientras que las que tenian familias numerosas fueron las que más solicitaron los servicios de planeamiento familiar. Otras de las variables-estado marital, educación y raza-mostraron asociaciones consistentes con todos los tres servicios. Los efectos de la religión fueron mixtos.

La aceptación del planeamiento de la familia aumentó al final del período de estudio, cuando estos servicios fueron ofrecidos abiertamente en la clínica postnatal.

El efecto de la distancia quedó demostrado claramente. La asistencia a la clínica postnatal disminuyó marcadamente de acuerdo con el aumento en la distancia al hospital. La probabilidad de que se visitara cualquiera de las cuatro clínicas que ofrecian servicios de planeamiento de la familia estaba igualmente relacionada con el grado correspondiente de accesibilidad a las mismas.

Una implicación práctica del estudio es que esta clase de análisis puede usarse para separar las categorias particulares de mujeres que requieren incentivos adicionales para que acudan a las clínicas. El estudio sugiere tambien que puede incrementarse notablemente la asistencia estableciendo clinicas secundarias dispersadas de forma que se aumente su accesibilidad.

Zusammenfassung-Auf der Suche nach Gründen für die geringe Benutzung von Mütterfürsorgediensten wurden 774 Schwangerschaftspatientinnen in zwei Spitälern in der Nähe von Detroit im Jahre 1964 befragt und später deren Besuch in Postpartum-Kliniken und in drei Familienplanungskliniken weiterverfolgt. Die meisten dieser Patienten kamen von den niedrigen Verdienstgruppen.

Durch fünf oder mehr als fünf Besuche in pränatalen Kliniken als ausreichend bezeichnete vorgeburtliche Pflege wurde von 64 Prozent der befragten Frauen berichtet. Nachfolgende Aufzeichnungen der Kliniken zeigten, dass 35 Prozent der für Postpartum-Kliniken eingetragenen Patienten auch tatsächlich von diesen Diensten Gebrauch machten und dass 22 Prozent aller befragten Frauen bei der einen oder anderen der Kliniken um Geburtsregelungsdienste ansuchten. Bei Frauen, welche zufolge der Aufzeichnungen die pränatalen Kliniken regelmässig besucht hatten, bestand auch grosse Wahrscheinlichkeit, dass dieselben die Postpartum-Kliniken ebenfalls besuchen und von Geburtsregelungsdiensten Gebrauch machen wirden.

Drei Gruppen von charakteristischen Merkmalen wurden auf ihren Zusammenhang mit Klinikbesuchen untersucht. Die erste Gruppe, nämlich die mit subjektiven Merkmalen, umfasste Patientinnen, die ihre Stellungnahme gegenüber den Kliniken ausgedrückt und ihre Absicht, dieselben zu besuchen oder auch nicht, bekanntgegeben hatten. Die zweite Gruppe bestand aus Frauen mit objektiveren Merkmalen, einschliesslich der Anzahl der lebenden Kinder, des Alters, des Familienstandes Erziehung, Rasse, der religiösen Einstellung 
und der Frequenz von Kirchenbesuchen. Die dritte Gruppe beinhaltete zwei durch Unstände bedingte Varianten-nämlich die Entfernung der Kliniken von derWohnung der Patientinnen und den Monat der Entbindung.

Zufolge wesentlicher wechselseitiger Beziehungen zwischen diesen beiden Varianten war es erforderlich, ein statistisches Kontrollsystem einzuführen, um die "rein statistischen Wirkungen" jeder einzelnen Variante auf Klinikbesuche unter Ausschluss anderer Variablen zu zeigen. Das dafür gewählte Verfahren-mehrfache Klassifizierungsanalyse-erbrachte eine Reihe von Gleichungen zur Vorhersage der entsprechenden Klinikbesuche.

Die Analyse zeigte, dass vorher ausgedrückte Stellungsnahmen und Absichten der Patientinnen selbst nichts zu der Voraussage der Besuchsanzahl unter Berücksichtigung der objektiven Merkmale hinzuzufügen hatten.

Alle obenerwähnten objektiven Varianten standen in beachtenswerter Beziehung zu den Klinikbesuchen. Einige davon wiesen ganz verschiedenartige Beziehungen zu der Benutzung der verschiedenen Mütterfürsorgedienste auf. Zum Beispiel war die Anspruchnahme der vorgeburtlichen und postpartum Pflege bei Frauen aus der niedrigen Verdienstgruppe höher, während Frauen mit vielen Kindern diejenigen waren, die die Geburtsregelungsdienste benutzten. Andere Variablen wie Familienverhältnisse, Erziehung und Rasse wiesen ständige Assoziationen mit allen drei Diensten auf. In religiöser Hinsicht zeigten sich gemischte Effekte.

Annahme der Geburtsregelungsdienste wuchs am Ende der Studienperiode, da dann diese Dienste öffentlich von Postpartum-Kliniken angeboten wurden.

Der Einfluss von Wohnplatzentfernung auf Klinikbesuche wurde klar zu Tage gebracht. Besuche in Postpartum-Kliniken fielen rapid bei zunehmender Entfernung vom Spital. Die Wahrscheinlichkeit von Besuchen in Kliniken, die Geburtsregelungsdienste anboten, war ähnlicherweise einem Kompositmasstab in Bezug auf die Erreichbarkeit dieser vier Kliniken unterworfen.

Ein praktischer Hinweis dieser Studie besteht darin, dass diese Art von Analyse zur Aufdeckung spezieller Kategorien von Frauen dienen könnte, bei welchen ein besonderer Ansporn für Klinikbesuche angebracht ist. Es wird auch angeregt, dass diese Besuche durch Errichtung verstreuter Zweigkliniken zum Zwecke der leichteren Erreichbarkeit beträchtlich erhöht werden könnten. 